\section{The Learner-Centered Paradigm of Education}

\author{
Sunnie Lee Watson
}

\author{
Charles M. Reigeluth \\ Contributing Editor
}

\section{Paradigm Change in Public Education}

This is the third in a series of four articles on paradigm change in education. The first (May-June 2008) addressed the need for paradigm change in education and described the AECT FutureMinds Initiative for helping state departments of education to engage their school districts in this kind of change. The second (July-August) described the School System Transformation (SST) Protocol that captures the current state of knowledge about how states can help their school districts to engage in paradigm change. This article describes the nature of the learnercentered paradigm of education, and it addresses why this paradigm is needed. The final article (NovemberDecember) will explore a full range of roles that technology might play in this new paradigm of education.

lacurner-contered paradigm. Then it describes the nature of the learner-contered paradigm.

\section{The Need for Change and the (Critical) Systems Approach to Educational Change}

Information-Age vs. Industrial-Age Education. Whereas society has shifted from the Industrial Age into what many call the 'Information Age' (Toffler, 1984; Reigeluth, 1994; Senge, Cambron-McCabe, Lucas, Smith, Dutton, \& Kleiner, 2000), current schools were established to fit the needs of an Industrial-Age society (see Tal)le 1). This factory-model, Industrial-Age school system has highly compartmentalized learning into sulject areas, and sludents are expected to learn the same content in the same amount of time (Reigeluth, 1904). The current sehool system strives for standardization and was not designed to meet individual learners' needs. Rather it was designed to sort students inlo laluorers and managers (sec Table 2), and students are forced to move on with the rest of the class regardless of whother or not they have learned the material, and thus many students accumulate learning deficits and eventually drop out.

The (Critical) Systems Approach to Educational Change. Systemic educational transformation strives to change the school system to a learner-centered paradigm that will moct all learners' educational needs. It is concerned with the creation of a completely new system, rather than a mere retooling of the current system. It entails a paradigm shift as opposed to piecemeal change. Repeated calls for massive reform of current cducational and training practices have consistently been published over the last several decades. This has resulted in an increasing recognition of the need for systemic transformation in education, as numerous piecemeal approaches to education reform 
Table 1. Key markers of Industrial vs. Information Age education (Reigeluth, 1994).

\begin{tabular}{|c|c|}
\hline $\begin{array}{c}\text { Industrial Age } \\
\text { Bureaucratic } \\
\text { Organization }\end{array}$ & $\begin{array}{c}\text { Information Age } \\
\text { Team } \\
\text { Organization }\end{array}$ \\
\hline $\begin{array}{c}\text { Autocratic leadership } \\
\text { Centralized control }\end{array}$ & $\begin{array}{c}\text { Shared leadership } \\
\text { Adversarial relationships } \\
\text { Standardization (mass } \\
\text { production, mass marketing, } \\
\text { mass communications, etc.) } \\
\text { Compliance } \\
\text { Conformity } \\
\text { Coccountability } \\
\text { Colationships } \\
\text { Customization } \\
\text { (customized } \\
\text { production, customized } \\
\text { marketing. customized } \\
\text { communications, etc.) } \\
\text { Initiative } \\
\text { of labor) }\end{array}$ \\
\hline
\end{tabular}

Table 2. Key features: Sorting vs. learning.

\begin{tabular}{|c|c|}
\hline $\begin{array}{c}\text { Sorting Based } \\
\text { Paradigm of } \\
\text { Education }\end{array}$ & $\begin{array}{c}\text { Learning Based } \\
\text { Paradigm of } \\
\text { Education }\end{array}$ \\
\hline Time-based & $\begin{array}{c}\text { Attainment-based } \\
\text { Person-based } \\
\text { Group-based } \\
\text { Teacher-based } \\
\text { Norm-based assessment }\end{array}$ \\
\hline
\end{tabular}

have been implemented and have failerl to significantly improve the state of education. Systemic transiormation sceks to shift from a paradigm in which lime is held constant, thereby forcing achievemont to vary, to ome designed specifically to meet the needs of IntormationAge learners and their communities by allowing students the time that cach necels to rad proticiency.

Systemic educational change draws hedvily from the work on critical systems theory (CST) (Flood \& lackson, 1991; Jackson, 1991a, 1991b; Watson, Watson, \& Reigeluth, 2008). CST has its roots in systems theory, which was established in the mid-twentieth cenlury by a multi-disciplinary group of researchers who shared the view that science had become increasingly reductionist and the various disciplines isolated. While the term system has been defined in a variely of ways by different systems scholars, the central notion of systems theory is the importance of relationships among elements comprising a whole.

CST draws heavily on the philosophy of Habermas
(1973, 1984, 1987). The critical systems approach to social systems is of particular importance when considering systems wherein inequality of power exists in relation to opportunity, authority, and control. In the 1980s, (ST came to the forefront (Jackson, 1985; Ulrich, 19831, influencing systems theory into the 1990s (Flood \& lackson, 1991; lackson, 1991a, 1991b). Liberating Systems Theory uses a post-positivist approach to analyze social conditions in order to liberate the oppressed, while also secking to liberate systems theory from tendencies such as self-imposed insularity, cases of internal localized subjugations in discourse, and libcration of system concepts from the inadec|uacies of objectivist and subjectivist approaches fFlool, 1990). lackson (1991b) explains that CST embraces five key commitments:

- critical awareness of examining values entering into arlual systems design;

- social awareness of recognition in pressures leading (o) popularization of certain systems theories and methodologies;

- dedication to human emancipation for full development of all human potential;

- informed use of systems methodologies; and

- informed development of all alternative positions and different theoretical systems approaches.

Banathe (1991) and Senge of al. (2000) apply systems theory to the design of educational systems. Banathy (1992) suggests examining systems through three lenses: a "still picture lens" to appreciate the components comprising the system and their rotationships; a "motion picture lens" to recognize the processes and dynamics of the system; and a "bird's cye view lens" to be aware of the relationships between the system and its peers and suprasystems. Songe of al. 2000) applies systems theory specifically to organizational learning, stating that the organization can learn to work as an inlerrelated, holistic learning community, rather than functioning as isolated kepartmonis.

Current Progress of Systemic Change in Education. While syslenic educational transformation is a relalively new movement in school change, there are currently various attempts to advance knowledge about it. Examples include: The Guidance System for Transforming Foducation (Jenlink, Reigeluth, Carr, \& Nelson, 1996, 1998), Duffy's Step-Up-To-Excellence (2002), Schlechty's 1997, 2002) guidelines for leadership in school reform, Hammer and Champy's (1993, 2003) Process Reengineering, and Ackoff's (1981) Idealized Systems Design.

There are also stories of school districts making fundamental changes in schools based on the application of systemic change ideas. One of the best practices of systemic transformation is in the Chugach 
School District (CSD). The students in CSD are scattered throughout 22,000 square miles of remote area in South-central Alaska. The district was in crisis twelve years ago due to low student reading ability, and the school district committed to a systemic transformation effort. Battino and Clem (2006) explain how the CSD's use of individual learning plans, student assessment binders, student learning profiles, and student life-skills portfolios support and document progress toward mastery in all standards for each learner. The students are given the flexibility to achieve levels at their own pace, not having to wait for the rest of the class or being pushed into learning beyond their developmental level. Graduation standards exceed state requirements as students are allowed extra time to achicve that level if necessary, but must meet the high rigor of the graduation level. Student accomplishment in academic performance skyocketed as a result of these systemic changes (Battino $\&$ Clem, 2006).

Caine (2006) also found strong positive changes through systemic educational change in extensive engagement on a project called "Learning to Learn" in Adelaide, South Australia, an initiative of the South Australian Government that covered a network ol over 170 educational sites. From preschool to 12 th grade, brain-based, learner-contered leaming environments were combined with a larger sed of systemic changes, leading to bolh better student arhievement and significant changes in the culture and operation of the system itself.

\section{Imagining Learner-Centered Schools}

Given the need for paradigm change in school systems, what should our schools look like in the future? The changes in society as a whole reflect a need for education to focus on learning rather than sorting students (McCombs \& Whisler, 1997; Reigeluth, 1997; Senge et al., 2000; Tofiler, 1984). A large amount of research has been conducted to aclvance our understanding of learning and how the elucational system can be changed to better support it. There is solid research about brain-based learning, leanercentered instruction, and the psychological principles of learners that provide cducators with a valuable framework for the Informalion-Age paradign of education (Alexander \& Murphy, 1993; Bransford, Brown, \& Cocking, 1999; Hannum \& McCombs, 20(18; Lambert \& McCombs, 1998; McCombs \& Whisler. 1997).

APA Learner-Centered Psychological Principles. With significant research showing that instruction should be learner-centered to meet all students' needs, there have been several efforts to synthesize the knowledge on learner-centered instruction. First, the American Psychological Association conducted wide-ranging research to identify learner-centered psychological principles based on educational research (American Psychological Association's Board of Educational Afiairs, 1997; Lambert \& McCombs, 1998). The report presents 12 principles and provides the research evidence that supports each principle. It categorizes the psychological principles into four areas: (1) cognitive and metacognitive, (2) motivational and affective, (3) developmental and social, and (4) individual difference factors that influence learners and learning (see Table $3)$.

National Research Council's "How People Learn." Another important line of research was carried out by the National Research Council to synthesize knowledge about how people learn (Bransford et al., 1999). A two-vear study was conducted to develop a synthesis of new approaches to instruction that "make it possible for the majority of individuals to develop a deep understanding of important subject matter" (p. 6). Their analysis of a wide range of research on learning emphasizes the importance of customization and personalization in instruclion for each individual leamer, self-regulated learners taking more control of thoir own learning, and baciliating deep understanding of the subject matter. They describe the crucial need for, and characteristics of, learning environments that are learncr-centered and learning-community centered.

Learner-Centered Schools and Classrooms. McCombs and colleagues (Baker, 1973; Lambert \& McCombs, 1998; McCombs \& Whisler, 1997) also address these new needs and idcas for instruction that supports all students. They identify two important features of learner-centered instruction:

...a focus an individual learners (their heredity, experi-
ences, perspectives, backgrounds, talents, interests,
capacities, and noeds) landl a tocus on learning the
best avalable knowledge about learning, how it
occurs, and what teaching practices are most effective
in promoting the highest levels of motivation, learning,
and achievement for all learners). (McCombs \&
Whisler, $1997, p .11$ )

This twofold focus on learners and learning informs and drives educational decision-making processes. In learner-centered instruction, lcarners are included in these educational decision-making processes, the diverse perspectives of individuals are respected, and lcarners are treated as co-creators of the learning process (McCombs \& Whisler, 1997).

Personalized Learning. Personalized Learning is part of the learner-centered approach to instruction, dedicated to helping each child to engage in the learning process in the most productive and meaningful way to optimize 
Table 3. Learner-Centered Psychological Principles (American Psychological Association's Board of Educational Affairs, Center for Psychology in Schools and Education, 1997).

\begin{tabular}{|c|c|}
\hline \multicolumn{2}{|r|}{ APA Learner-Centered Psychological Principles } \\
\hline $\begin{array}{l}\text { Cognitive and } \\
\text { Metacognitive Factors }\end{array}$ & $\begin{array}{l}\text { - Nature of the learning process. } \\
\text { The learning of complex subject matter is most effective when it is an intentional process } \\
\text { of constructing meaning from information and experience. } \\
\text { Goals of the learning process. } \\
\text { The successful learner, over time and with support and instructional guidance, can create } \\
\text { meaningful, coherent representations of knowledge. } \\
\text { - Construction of knowledge. } \\
\text { The successful learner can link new information with existing knowledge in meaningful } \\
\text { ways. } \\
\text { Strategic thinking. } \\
\text { The successful learner can create and use a repertoire of thinking and reasoning } \\
\text { strategies to achieve complex learning goals. } \\
\text { Thinking about thinking. } \\
\text { Higher-order strategies for selecting and monitoring mental operations facilitate creative } \\
\text { and critical thinking. } \\
\text { Context of learning. } \\
\text { Learning is influenced by environmental factors. including culture, technology, and } \\
\text { instructional practices. }\end{array}$ \\
\hline $\begin{array}{l}\text { Motivational and } \\
\text { Affective Factors }\end{array}$ & $\begin{array}{l}\text { - Motivational and emotional influences on learning. } \\
\text { learn, in turn, is influenced by the individual's emotional states, beliefs, interests and goals, } \\
\text { and habits of thinking. } \\
\text { - Intrinsic motivation to learn. } \\
\text { The learner's creativity, higher-order thinking. and natural curiosity all contribute to } \\
\text { motivation to learn. Intrinsic motivation is stimulated by tasks of optimal novelty and } \\
\text { difficulty, relevant to personal interests, and providing for personal choice and control. } \\
\text { - Effects of motivation on effort. } \\
\text { Acquisition of complex knowledge and skills requires extended learner effort and guided } \\
\text { practice. Without learners motivation to learn. the willingness to exert this effort is unlikely } \\
\text { without coercion. }\end{array}$ \\
\hline $\begin{array}{l}\text { Developmental and } \\
\text { Social Factors }\end{array}$ & $\begin{array}{l}\text { Developmental influences on learning. } \\
\text { As individuals develop, there are different opportunities and constraints for learning. } \\
\text { Learning is most effective when differential development within and across physical, } \\
\text { intellectual, emotional, and social domains is taken into account. } \\
\text { - Social influences on learning. } \\
\text { Learning is influenced by social interactions, interpersonal relations, and communication } \\
\text { with others. }\end{array}$ \\
\hline $\begin{array}{l}\text { Individual } \\
\text { Differences Factors }\end{array}$ & $\begin{array}{l}\text { - Individual differences in learning. } \\
\text { Learners have different strategies. approaches, and capabilities for learning that are a } \\
\text { function of prior experience and heredity. } \\
\text { - Learning and diversity. } \\
\text { Learning is most effective when differences in learners' linguistic, cultural, and social } \\
\text { backgrounds are taken into account. } \\
\text { Standards and assessment. } \\
\text { Setting appropriately high and challenging standards and assessing the learner as well as } \\
\text { learning progress - including diagnostic, process, and outcome assessment -are integral } \\
\text { parts of the learning process. }\end{array}$ \\
\hline
\end{tabular}

each child's leaming and success. Personalized Learning was cultivated in the 1970s by the National Association of Secondary School Principals (NASSP) and the Learning Environments Consortium (LEC) International, and was adopted by the special education movement. It is based upon a solid foundation of the NASSP's educational research findings and reports as to how students learn most successfully (Keefe, 2007; Keefe \& Jenkins, 2002), including a strong emphasis on parental involvement, 
more teacher and student interaction, attention to differences in personal learning styles, smaller class sizes, choices in personal goals and instructional methods, student ownership in setting goals and designing the learning process, and technology use (Clarke, 2003). Leaders in other liolds, such as businessman Wayne Hodgins, have presented the idea that learning will soon become personalized, where the learner both activates and controls her or his own learning environment (Duval, Hodgins, Rehak, \& Rolsson, 2004).

Differentiated Instruction. The reconl movement in differentiated instruction is also a respense to the need for a learning-focused as opposed lo a sorling-iocused approach to instruction and colucalion in schools. Differentiated instruction is an approach thal enables teachers to plan strategically to moet the needs of every student. It is elecply grounded in the prine iple that there is diversity within any group) of leamers and that teachers should adjust students' learning aporionces accordingly (Tomlinson, $1999,2001,200$;). This draws from the work of Vygolsky (1980), os exially his "zonc of proximal development" (ZP|) i, and from classroom researchors. Researchers found that with difiorontiated instruction students learneel more and foll beder aboul themselves and the subject area being studied (Tomlinson, 2001). Evidence iurlher inclicates Lhal students are more successful and motivated in sehools if they learn in ways that are responsive lo their readiness levels IVygotsky, 1986), persomal interests, and learning profiles (csikszontmithalvi, 1900); Sternberg, Torit, \& Crigor(mko), 10983i. The god of differentiated instruction is to adelress these theree characteristics for anch suckent Tomolinson, 2001, 2003).

Brain Research and Brain-Based Instruction. Anolher arca of study that gives us an understanding of how people learn is the work on lorain research which describes how the brain lunctions. Caine and colleagues $(1997,2005,2006)$ provide a usciul summary of work on how the brain funclions in the process of learning through the 12 princ iples of brainbased learning. Brain-based learning begins when learners are encouraged to actively immorse themselves in their world and their learning experiences. In a school or classroom where brain-based loarning is being practiced, the significance of diverse individual learning styles is taken for granted be toachers and administrators Caine \& Caine, 1907). In these classrooms and schools, learning is accilitated for cach individual student's purposcs and meaning, and the concept of learning is approached in a completely different way from the current classrooms that are set up for sorting and standardization.

\section{An Illustration of the New Vision}

What might a learner-centered school look like? An illustration or synthesis of the new vision may prove helpful.

Imagine that there are no grade levels for this school. Instead, each of the students strives to master and check off their attainments in a personal "inventory of attainments" (Reigeluth, 1994) that details the individual student's progress through the district's required and optional learning standards, kind of like merit badges in Scouting. Each student has different levels of progress in every attainment, according to his or her interests, talents, and pace. The student moves to the next topic as soon as she or he masters the current one. While ach student must reach mastery level before moving on, students also do not need to wait for others who are nol yet at that level of learning. In essence, now, the schools hold time constant and student laarning is thereby forced to vary. In this new paradigm of the learner-centered school, it is the pace (learning (ime) that varies rather than student learning. All sludents work at their own maximum pace to reach mastery in ach attainment. This individualized, customized, and self-paced learning process allows the school district to realize high standards for its students.

The teacher takes on a drastically different role in the learning process. She or he is a guide or facilitator who works with the student for at least four years, building a long-term, caring relationship (Reigeluth, 1994). The tacher's role is to help the student and parents to decide upon appropriate learning goals and to help identily and facilitate the best way for the sturlent to achieve those goals - and for the parents to support their student. Therefore, each student has a porsonal loarning plan in the form of a contract that is jointly developed every two months by the student, parents, and teacher.

This system enhances motivation by placing greater responsibility and ownership on the students, and by offering truly engaging, often collaborative work for students (Schlechty, 2002). Teachers help students to direct their own learning through the contract clevelopment process and through facilitating realworld, independent or small-group projects that focus on developing the contracted attainments. Students learn to set and mect deadlines. The older the students get, the more leadership and assisting of younger sturlents they assume.

The community also works closely with schools, as the inventory of attainments includes standards in service learning, career development, character development, interpersonal skills, emotional development, technology skills, cultural awareness, and much more. Tasks that are vehicles for such learning are authentic tasks, often in real community environments that are 
rich for learning (Reigeluth, 1994). Most learning is interdisciplinary, drawing from both specific and general knowledge and interpersonal and decision-making skills. Much of the focus is on developing deep unclerstandings and higher-order thinking skills.

Teachers assess students' learning progress through various methods, such as computer-based assessment embedded in simulations, observation of student performances, and analysis of student products of various kinds. Instead of grades, students receive ratings of "emerging," "developing," "proficient" (the minimum required to passi, or "expert."

Each teacher has a cadre of students with whom she or he works for several years-a developmental stage of their lives. The teacher works with 3-10 other teachers in a small learning community (SLC) in which the learners are multi-aged and got lo know each other well. Students get to choose which teacher they want (stating their first, second, and third choice), and teacher bonuses are based on the amount of demand for them. Each SLC has its own budget, based mainly on the number of students it has, and makes all its own decisions about hiring and firing of its staff, including its principal (or lead teacher). Each SLC also has a school board made up of teachers and parents who are elected by their peers.

While this illustration of a learner-centered school is based on the various learner-contered approaches to instruction reviewed earlier and the latest extucational research, this is just one of many possible visions, and these ideas need revision, as some are likely to vary from one community to another, and most need further elaboration on details. Nonctheless, this picture of a learner-centered paradigm of schooling could help us to prevail over the industrial-age paradigm of learning and schools so that we can create a better place for our children to learn.

\section{Conclusion}

Our society needs fearner-centered schools that focus on learning rather than on sorting $(M C$ C Combs \& Whisler, 1997; Reigeluth, 1997; Senge el al., 2000; Toffler, 1984). New approaches to instruction and education have increasingly been advocated to meet the needs of all learners, and a large amount of research has been conducted to advance our understanding of learning and how the educational system can be changed to better support it Alexancler \& Murphr, 1993; McCombs \& Whisler, 1997; Reigeluth, 1997; Senge et al., 20001. Nevertheless, transforming school culture and structure is not an easy task.

Isolated reforms, typically at the classroom and school levels, have been attempted over the past several decades, and their impact on the school system has been negligible. It has become clear that transforming the paradigm of schools is not a simple job. Teachers, administrators, parents, policy-makers, students, and all other stakeholder groups must work together, as they cannot change such a complex culture and system alone. In order to transform our schools to be truly learner-centered, a critical systems approach to transformation is essential.

The first article in this series (Reigeluth \& Duffy, 20081 described the FutureMinds approach for state education departments to support this kind of change in their school districts. The second article (Duffy \& Reigeluth, 2008b) described the School System Transtormation (SST) Protocol, a synthesis of current knowledge about how to help school districts use a critical systems approach to transform themselves to the learner-centered paradigm of education. Hopefully, with state leadership through FutureMinds, the critical sustems approach to educational change in the SST Protocol, and the new knowledge about learnercentered instruction, we will be able to create a better place for our children to learn and grow. However, this task will not be easy. One essential ingredient for it to succeed is the availability of powerful tools to help teachers and students in the learner-centered paradigm. The fourth article in this series will address this need.

\section{References}

Ackorl, R. 1. 11981). Crealing the corporate fulure. New York: John Wiley \& Sons.

Alexander, P. A. \& Murphy, P. K. (1993). The research base for APA's learner-centered psychological principals. In B. L. MeCombs (Chair), Taking research on learning seriously: Implications for teacher education. Invited symposium at the Annual Meeting of the American Psychological Association, New Orleans.

American Psychological Association's Board of Educational Afiairs, Center for Psychology in Schools and Education. (1903). Leamer-centered psychological principles; hetp:l/ imww.apa.org/cd//cp2//cp 14.htm/

Baker, f. 11973). Organizational systems: Ceneral systems approaches to complex organizations. Homewood, IL: R. D. Irwin.

Banathy, B. H. (1991). Systems design of education: A journey to create the future. Englewood Cliffs, NI: Educational Technology Publications.

Banathy, B. H. 11992). A systems view of education: Concepts and principles for effective practice. Englewood Cliffs, N): Educational Technology Publications.

Battino, W. \& Clem, J. (2006). Systemic changes in the Chugach School District. TechTrends, 50(2), 51-52.

Branstord, J., Brown, A., \& Cocking, R. (Eds.). (1999). How people learn: Brain, mind, experience, and school. Washington, DC: National Academy Press.

Caine, R. N. (2005). 12 brain/mind learning principles in action: The fieldbook for making connections, teaching, 
and the human brain. Thousand Oaks. CA: Corwin Press.

Caine, R. N. (2006). Systemic changes in public schools through brain-based learning. Techtrends, $50121,52-53$.

Caine, R. N., \& Caine, G. 11997. Folucation on the edge of possibility. Alexandria, VA: Association tor Supervision \& Curriculum Development.

Clarke, 1. (2003). Personalized karning and personalized taching. In I. Dimartino, I. Clarke, \& D. Wolk Eds.?, Personalized leaming: Preparing hish sthool students to crade their lutures. Lanhan, MD): Scarecrow press.

Csikszentmihalyi, M. 11990 . Flow: The psichology of optimal experience. Now York: Harper \& Row.

Duffy, F. M. (2002). Step) L/P To Fucellence: in innowalive approach to managing and rewarding performances in school systems. Lanham, MID: Scarecrow Press.

Duffy, F. M., \& Reigeluth, (.. M. $120(1) 81$. The school system transtomation iSSTy probecol. Eelucational fechomology, $48(4), 41-49$

Duval, F., Hodgins, W., Rohak, D., \& Robsom, R. 12004t1. Learning objocis symposium special iscue gerest edterial.

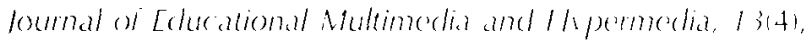
3.31 .

Flood, R. L. 11990). Liberating systems theory: Foward critical

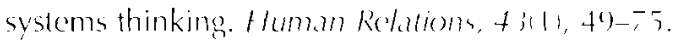

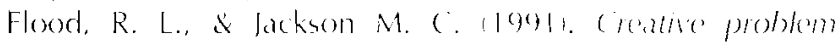
solving: Hodal systoms inkerement New York: kohn Wiles and Sons.

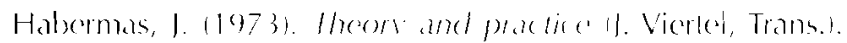
Boston: Beacon Press.

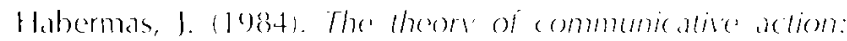

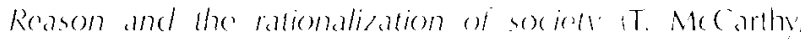
Trans.). Beston: Beacon Pross.

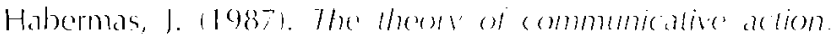

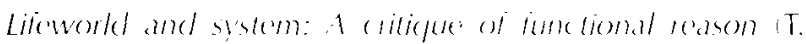
Me Carthy, Trans.) Buston: Beacon Press.

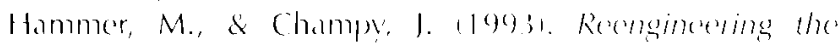
comporation: A munitesto tor business wotution. New York: I harper Business.

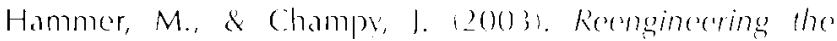
comporation: A manituelo for business revolution 11 st Harper Business Essenlials phk. ad. Now York: I larper Business Fssentisls.

Hannum, W. H., \& Mccombs, B. L. Lzhost. Entancing distance fearning for loclas's vouth with leanerecentered

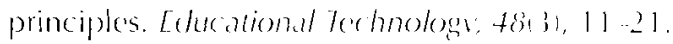

lackson, M. C. 11985!. Social systeme theors and practice: The need for a critical appreach. International foumal of Cicneral Systems, $10131,1.35-151$.

fackson, M. C. (1991al. The origins and nature of critical suslems thinking. Systems Practice, +12), $131-149$.

lackson, M. C. 19991bi. Post-nodernism and conlemporary systems thinking. In R. C. Floorl \& M. C. lackson ifds.), Critical systems thinking (p). 287-302). New York: John Wiley \& Sons.

Jenlink, P. M., Reigcluth, C. M., Carr, A. A., \& Nelson, 1. M. (1996). An expedition for change. TechTrends, 4/11, 21 30 .

Jenlink, P. M., Reigeluth, C. M., Carr, A. A., \& Nelson, L. M. (1998). Guidelines for facilitating systemic change in school districts. Systems Research and Behavioral Science, $15131,217-233$.

Keefe, 1. (2007). What is personalization? Phi Delta Kappan, $89131,217-223$.

Kecte, W. \& Jenkins, J. (2002). A special section on personalized instruction. Phi Desta Kappan. 83(6), 440-448.

Lambert, N. M., \& McCombs, B. (Eds.). (1998). How students learn: Reforming schools through learner-centred cducation. Washington, DC: American Psychological Association.

Mc Combs, B., \& Whisler, I. (1997). Tho learner-centered classroom and school. San Francisco: Jossey-Bass.

Reigeluth, C. M. 1994). The imperative for systemic change. In C. M. Reigeluth \& R. J. Garfinkle (Eds.), Systemic change in education. Englewood (lifiss, NJ: Educational Technology Publications.

Reiguluth, C. M. 11997). Educational standards: To standardize or to customize learning? Phi Della Kappan, $7013), 202-206$.

Reigcluth, C. M., \& Dutty, F. M. 2008). The AECT futureminds initiative: Transtorming America's school systems. felucaliomal 7rechology, 4833), 4.5-49.

Schlechty. P. (. 11997). Inventing better schools: An action phen for educalional rotom. San Francisco: Josscy-Bass.

Schlechty, P. C. 20021. Woking on the work: An artion phan for teachers, principals, and superintendents. San Francisco: Jossev-Bass.

Songe, P., Combron-Mccabe, N., Lucas, T., Smith, B., Dulton. I., \& Kleiner, A. 2000). Schools that learn: A filth discipline liodelboes ion educalors, parents, and everyone who cares aldenteduation. Toronto: Currency.

Stermberg, R., Torft, B., \& Crigorenko, E. 1998). Teaching driarchically improves student achievement. Loumal of Educational Parchology: 90131, 374-384.

Tefiler, A. I 984 t. The Whad wave. New York: Banlam.

Tomlinson, (. A. 11909$)$. The diflerentioted chassroom: Respending to the needs of all leamers. Alexandria, VA: Associalion for Supervision and Curriculum Development.

Tomlinson, (. A. 2001 ). How to rifierentiate instruction in mixed-ablity chassooms and ed.). Alexandria, VA: Association for Supervision and Curriculum Development.

Tomlinson, C. A. 12003$)$. Fullilling the promise of the diflementiated rassrom: Strategies and loots for responsive teaching. Alexandria, VA: Association for Supervision and Curriculum Development.

Ulich, W. 19831. Critical heuristics of social planning: A new approach to practical philosophy. Bern, Swilzerland: Haupt.

Vygotsky, L. (1986). Thought and language (A. Kozulin, Trans.). Cambridge, MA: MIT Press (original work published 19261.

Watson, S. L., Watson. W., \& Reigeluth, C. M. (2008). Systems design for change in education and training. In J. M. Spector, M. D. Merrill, J. van Merriênboer, \& M. P. Driscoll (Eds.), Handbook of research for educational communications and technology (3rd ed.). New York: Routledge/Lawrence Erlbaum Associates. 